\title{
21. Governance, Globalisation and the PNG Media: A survival dilemma
}

\section{Joe R. Kanekane}

This chapter attempts to examine how the PNG media has promoted good governance. It also examines some of the global developments imposed in the country and how these have been embraced. But the bulk of this paper will look at some of the hurdles faced by the PNG media in attempting to better disseminate governance issues. Some recommendations are offered to solve this dilemma.

\section{Background}

The demise of the reputable weekly newspaper the Independent in May 2003 heralded a reality check for the other forms of media seeking to survive in the tough and depressed PNG economy. Despite significant economic reforms by the People's Democratic Movement (PDM) Government headed by Sir Mekere Morauta, their fruits were marginal. Media organisations confronted the truth; the operating environment appeared to be tough. Costs were high and radical interventions were needed.

The Independent, one of the pillars of investigative journalism in PNG as well as an advocate of good governance and transparency, was shelved after 23 years. During those years, it unravelled some of the country's worst corruption scandals, from the Tos Barnett inquiry into the forestry sector, to the controversial purchase of the Cairns Conservatory, and the Defence Force Retirement Fund's purchase of the Vanimo Motel. The Independent's demise was a blow, at least to the checks and balances in the PNG media, and particularly to coverage of issues in detail. While other media concentrated on day-to-day issues, this publication was meticulous, conservative and thorough, giving decision-makers insights into debates. Anna Solomon (2005), former editor-in-chief of the Word Publishing Group, recalled the Independent's coverage of Bougainville crises, where, despite threats of legal suits and confrontation, the paper pressed on printing stories about atrocities allegedly committed by PNG Defence Force soldiers. The real reason for the end of the Independent was that its parent company, Word Publishing, was hit with cash crises. It had to make drastic decisions. Despite staff reductions and folding the popular Weekend Sports and the Saturday Independent, with its controversial Australian turf guide, the paper was not able to sustain itself.

The introduction of The National in 1993 had taken its toll; media competition in the country was becoming tough. The media market in the country was small and daily newspapers such as the Post-Courier and The National had to embark 
on aggressive marketing strategies. The printing of regional newspapers, featuring news and developments in regions beyond Port Moresby, proved too costly. The Independent had opened regional bureaus in Mt Hagen, Lae, Rabaul, Madang and Bougainville in an attempt to improve its circulation.

FM and community radio stations have mushroomed, offering specific programs for their listeners and with restricted frequencies. The cost of doing media business in PNG has been high with little return. Yet, with a very low literacy rate in PNG, the media business has continued to excel in its fundamental role of educating and informing the masses - although at a price. On a global scale, the PNG media had come of age, embracing global developments of free markets and capitalism.

\section{The PNG media today}

There is no doubt that the privileges enjoyed by the media organisations in PNG are considerable when compared with the restrictions and gags on media freedom many other countries face, some as close as its Polynesian neighbour, the Kingdom of Tonga. Media establishments are numerous, giving the public the opportunity to choose from a wide range of information sources to satisfy their needs. PNG is dynamic in technology and the pace of changes and reporting styles are akin to those of the Western media. But, as in all developing nations, much of PNG's population is rural based and there comes the key question: are these people informed and knowledgeable about governance issues? And are they contributing to make the country truly vibrant and robust?

H. C. Brookfield's (1972) observation remains true despite the advent of technology, access and education levels of Papua New Guineans. He claimed that towns and cities in Melanesian countries were 'poorly informed'. He went further to claim that word-of-mouth was a pivotal link between those who have access to information and those who don't. Oseah Philemon, editor-in-chief of the PNG Post-Courier, says the country lacks a 'comprehensive and elaborative communication plan' where everyone is abreast of rapid changes. Speaking during the popular gun summit in Goroka in 2005, he was sceptical about the fundamental role of the media. Philemon admitted that access to the media was restricted despite the technological advances apparent in the country. He said, 'Newspapers were available only in towns; radio was listened to by those who could afford it, while TV was a luxury to many Papua New Guineans.' This dichotomy reflects contrasting scenarios in rural and urban settings. For advocates of good governance, this is not helpful as it falls short of reaching the country-wide audience, concentrating instead on the very few that can either read or have access to electronic media. The issues put forward are known only in one sector of the community while the rest miss out. 
An example is the campaign against HIV/AIDS. In November 2004, the chairman of the Special Parliamentary Committee on HIV/AIDS, Dr Banare Bun, launched the fourth phase of the HIV/AIDS campaign targeting the stigmatisation of people living with HIV/AIDS. The objective was to ensure that those living with HIV/AIDS were accepted as members of the community. This effort was the result of a survey in 2004 in which 30 per cent of 2,000 people from the four regions of PNG who were interviewed were unsure about treating sufferers as fellow citizens. This is an interesting revelation because the HIV/AIDS publicity campaign had been prominent in all the main forms of the PNG media.

I have attempted to present these two cases as a prelude to my paper assessing whether the PNG media plays its fundamental role, which is to educate and inform the masses. In a diverse country such as PNG, the proper role of the media is often questioned. Does it have an obligation to inform the masses, should it be a partner in development or should it just concentrate on making a profit? Too often people don't necessarily understand the challenges faced by the media industry as it endeavours to sustain itself. It is true that PNG has media freedom, but along with that freedom comes responsibility. Former Prime Minister Sir William Skate's statement in Parliament on July 6, 2005, is a good example of the responsibility of journalists to get things right. The media had once again erroneously reported that former Deputy Prime Minister Mao Zeming was Skate's deputy. 'The media should check facts before reporting,' Skate said. The PNG media has operationalised a process where it goes ahead to report and then allows the aggrieved parties to defend themselves. David Robie has argued that the PNG media has not allowed itself sufficient scrutiny to be able to claim objectivity: 'The media now needs to subject itself to the same rigorous scrutiny that it applies to the nation's institutions for it to make a greater contribution to democracy.' While members of parliament have the privilege of explaining misconstrued facts on the floor of Parliament, the public have the unenviable task of pestering the media to seek redress, after publication.

Then there is the issue of sources and their credibility. When faced with a looming deadline, reporters sometimes invent a source to lend support to their story. Daniel Kapi (2002), former political adviser to Sir Michael Somare, queried how journalists got their information. According to Kapi, naming a source was often wishful thinking on the part of the reporter. Kapi, a long-time Pangu Pati stalwart, was also instrumental in the late 1980s in the deportation of respected ABC correspondent Sean Dorney. Mark Felt (2005) suggests that the use of two sources, as is the standard in the USA, is absolutely necessary so that journalists are not manipulated by a single source. Felt admitted to being the CIA source for the two journalists who broke the 'Watergate' scandal, which led to the demise of President Richard Nixon. 
Unfortunately PNG cannot be compared with the rest of the world because it has a very short history of independence. The sad trend has been its inability to keep experienced journalists. Many have moved to greener pastures while the young and inexperienced are attempting to make a mark in mainstream journalism. A huge vacuum then opens up and the treatment of news is more superficial than it ought to be. Moreover there is no journalists' union that can fight for the rights of journalists, so that they can be encouraged to remain in the mainstream. In essence, journalists are at the mercy of their employers, and are in some circumstances disadvantaged. Despite constant efforts to reactivate the union, support and commitment from the journalists have been abysmal. Meetings have taken place, suggestions made, interim executives appointed, and membership drives attempted, but all to no avail.

The PNG media has to fight for its survival and then squeeze in governance issues when it sees them as relevant, although there are no policies, criteria or obligations specifically to cover governance issues. Media organisations are aroused mainly through community commitment and paid messages.

\section{Governance and the PNG media}

During the 2001 Media Freedom Day celebrations at the Divine Word University, then resident $\mathrm{ABC}$ correspondent, Richard Dinnen, outlined the difficulties faced by the PNG media in reporting to the masses. He admitted that the PNG rural populace did not have enough positive news reported and there was a huge bias towards news from Port Moresby. He urged journalists to probe further into the rural areas and write about positive developments. Dinnen touched on the media's role in a country such as PNG and how it mirrors the changes and developments in places like Port Moresby.

\section{War against corruption}

When the PNG Media Council launched its 'War Against Corruption', I was elected Chairman of the Editors' Task Force, a group comprising senior PNG journalists. This group came directly under the auspices of the PNG Media Council, whose role was to provide direction and advice. One of our primary roles was to screen each and every file, piece of information and document that came before us. We met once every month and went through the files. While the awareness aroused by the campaign was appreciated, the response was poor outside Port Moresby.

I remember a file coming from Misima Island, where the author wanted our help to solve a domestic matter, something along the lines of an affair turned sour. Another file from Wewak wanted us to do a character check on an unfair selection of a candidate to a public service position. Another file from Port Moresby perceived us as a kind of Ombudsman and requested that we investigate a nepotistic practice within the organisation the author was working for. A village 
councillor in the Southern Highlands attempted to convey to us the failure of the provincial government to pay councillors' allowances, which, he claimed, amounted to something like a thousand kina.

We received a lot of files but then we had several difficulties.

First of all, we had to gather enough reporters to work on the stories systematically. The idea was to pass the information to everyone so that they could work on the stories separately. Those who were on my team were senior reporters with specific responsibilities and had to juggle their primary responsibility with this new role. We ran into a few hurdles. I was the chief political reporter and news director of the Independent and had to ensure that my own newsroom was fully functional while chairing this committee. Ruth Waram, another key member of our group, was business editor of the Post-Courier while Michael Asagoni was chief political reporter with the National Broadcasting Commission (NBC). Titi Gabi was chief of staff of EMTV. It was a big ask, blending the two roles. I was lucky as I worked for a weekly and the timing was okay. The others were committed and enthusiastic but just did not have enough time to work together with us; however, they were all ready and willing to help.

Secondly, most of the stories were merely allegations and lacked substance and facts for us to pursue. The authors also did not want to be identified and we could not deliberate on what was there.

Thirdly, the public expected us to write their stories the way they sent them to us. They were, I presume, desperate to have their grievances heard and seek redress, and many felt that we facilitated that role; however, they wanted results the moment the stories came out.

Fourthly, we weren't able to keep reporters when they were offered jobs elsewhere. Our key group became smaller as I succumbed to the closure of the Independent and took up a civil service job, while Waram joined the corporate circles and Robert Palme resigned from the Post-Courier. Jane Nuia also left and so did Collin Taimbari. Our core team was reduced and I could not do anything more than leave mainstream journalism. However, some of the stories that were run were effective. A director of a semi-government body resigned, while Parliament debated a number of issues including the PNG Raggianna Account in the Cayman Islands and many others. There were also changes in some government departments and awareness that the task force wasn't going to play around. Unfortunately, most of the impact of the stories was within Port Moresby and only one or two changes were made in the provinces.

As to whether this was successful, I could not say, but I don't think people really understood exactly what we were advocating. However, the 2002 election saw three-quarters of the sitting MPs lose their seats. Again, without concrete evidence, I cannot say whether the war against corruption had an impact, but 
it was obvious to me that those who really understood what we were pushing were urbanites. Many others were cynical about our modus operandi, because it was disjointed. I had phone calls from people saying that they wanted immediate action, and they wanted to know why some issues were taking longer than others to achieve results. Some people were not prepared to accept our role, nor did they appreciate exactly what we had set out to do. Former national editor Yehiura Hriewazi pointed out to me that our role was not to be the juror and the judge; it was merely to report and it was up to the authorities to take the next step. But the effort by the PNG media was a relief for those who did not otherwise have access to appropriate avenues to express their grievances.

\section{Daily coverage of governance-related issues}

Former Wantok editor Yakam Kelo commented on the dilemma his staff endured trying to simplify some issues. According to Kelo, often the generic messages are hard to dissect and, while attempting to simplify them, the gist of a story is lost.

Titi Gabi of PNGFM, on the other hand, is pressured by time restrictions and news and information is edited accordingly. As news director of one of PNG's most popular radio stations, her challenge is to ensure that the news is tight. News items on the Tok Pisin and English stations are carefully selected on their merits. Gabi is the only experienced journalist on the station and has young reporters who have just finished school. She says she often has to explain stories, verify them and put them into perspective before they go to air.

Dorah Masueng, news manager of the NBC, says there is no special treatment given to governance issues. She credits the Government with allowing the network to carry out its role without fear or favour. However, special programs promoted by UNICEF or the YWCA are prepaid. The airing of specific issues on governance would have to be paid for even if they were intended to address the community at large and contributed to a better PNG.

The law and justice sector also has to pay for its members to speak on FM radio stations. While issues of law and justice are critical to the progress of the nation, even promoting positive news about this sector's achievements has to paid for.

Daniel Korimbao, The National's night editor, says that while there is no specific emphasis on a particular area, governance issues are given prominence. He adds that The National has worked on its rural-reach strategy with its circulation manager travelling up and down the Highlands Highway opening outlets to sell the paper. These revelations prove that governance issues, in spite of their significance, don't receive special treatment. The onus again is on the anti-corruption agencies to produce their own media campaigns and often huge amounts of money are required to achieve this. 


\section{Global issues and the PNG media}

Global issues are ever present in the PNG media. Because of the freedom of expression provisions in the Constitution, the reporter plays a crucial role, one more robust than in many other countries.

Section 51 of the Constitution guarantees freedom of information and the profession of journalism embraces that pillar; however, foreign cultural imperialism is well and truly apparent in the country. The BBC and the ABC are accessible on the FM band. Pay TV offers CNN as well as a number of channels in French, Bahasa and Korean.

EMTV relays shows such as McLeod's Daughters, Blue Heelers, Who Wants To Be A Millionaire?, Survivor, The Apprentice and a couple of outdated programs. On top of that it relays the US Open, State of Origin rugby league matches and one-day cricket matches. Because of the costs of pay TV, viewers have no choice but to view these programs. Before the introduction of EMTV, rugby league was the game of choice, however, today on the streets of PNG, little kids play cricket.

Kevin Pamba (2005), in his Note Book column, concurs with this scenario adding that, 'The news of the world that is reproduced daily by the PNG Media comes from major Western news syndicates. These reports carry a Western spin or bias in the language chosen.'

The international media has become so persuasive and pervasive that it erodes national cultures and traditional values. Papua New Guineans resent this and have attempted to call for changes. Urban Papua New Guineans are well versed in developments in globalisation, privatisation and corruption. The advocates of globalisation are the overseas agencies. The World Bank's user-pays policy, privatisation and land reforms have all been met with increased resistance. The PNG media, although meant to report fairly and accurately, has been under a lot of scrutiny. Its reporting style has been subject to compromise, often contrary to the spirit of its intent.

In March 2005, The National ran a series of articles against the controversial Enhanced Cooperation Package (ECP), particularly the presence of Australian police. Several front-page articles appeared without by-lines, and, in subsequent weeks, conveniently, stories attributed to 'a source' started appearing. As the weeks unfolded and the debate on the ECP grew, it became apparent that the 'source' was linked to the police union. At that time, The National did not attempt fairness by reporting the positive developments of the ECP presence.

In April 2004, the Post-Courier featured an article about looming ethnic warfare between the Kimis of Okapa and Mt Hagen landowners, over a lost shoe. As a result, there were disruptions to businesses, roadblocks and millions of kina were lost including supplies to the giant Porgera mine in Enga Province. 
Hundreds of commuters were stranded in Goroka and Lae as police in Mt Hagen mediated in the crisis. Western Highlands Provincial Police Commander, Winnie Heano, commented later that the Post-Courier report was wrong. He stated that the second-hand information the reporter had obtained had been taken out of context, resulting in the mayhem. Fortunately, no lives were lost, however, the businesses in the Simbu, Western, Enga and Eastern Highlands provinces incurred significant losses.

On Sunday July 17, 2005, during the 6 pm news, Government Chief Secretary, Joshua Kalinoe, accused EMTV's John Eggins of being irresponsible. A week earlier Eggins had insinuated in his 'Sunday Commentary' that the Chief Secretary had recommended a candidate for the vacant Attorney-General's position. Kalinoe said the media, like public offices, should play a responsible role because of its power.

Former Chief Ombudsman Charles Maino (1995) had raised concerns about the power of the media and its need to be responsible. He stated that freedom of the press was not a privilege but a responsibility that required all involved in the mass media to be independent, impartial, honest and fair in all methods of reporting.

These are examples of subjectivity in reporting. The ECP was geared towards assisting the country and improving governance. One component of the package involved the presence of Australian police on the streets of Port Moresby and, for a while, crime seemed to have declined. Moreover, more crimes were reported to police than previously, a reflection of the confidence the public had in the Australian police.

The third example shows the power of television. Eggins, a respected commentator, attempted to query the delay on the appointment of a permanent Attorney-General. But the way his comments were perceived took them out of their original context and they were rebutted in the wrong spirit. In spite of the significance of the issue, resentment from the top levels of government was ominous.

But it shows that television is used well and can bring home the desired messages. The PNG media does not have criteria to consult when choosing stories and operates on the basis that, in the editor's judgment, people need to know certain information and certain issues are significant. Global governance issues might be well received in other nations, but the PNG media prides itself on freedom of information and, in practice and in the context of commercial reality, that notion often means giving less prominence to global governance issues than to cases of rape, murder or a mass prison breakout. 


\section{Critical analysis of the PNG media's role towards governance}

The PNG media is keen to assist in governance issues but has to face some stark realities for its own survival. I want to now dwell on some key issues that might have some effect on the dissemination of governance issues.

\section{a. Journalists}

Journalists are low paid despite being well educated. An average cadet reporter is paid between K150-K200 a week and he/she has to survive in a place like Port Moresby, with skyrocketing rental costs and high day-to-day expenses. Compare that with other professionals such as lawyers, doctors and accountants. Journalists' salaries are in no way comparable. There is therefore a high turnover of journalists joining the private sector and newsrooms are filled with mainly young reporters. Family demands have seen experienced reporters leaving the mainstream media for well-paid government jobs, leaving huge gaps of experience and aptitude in the reporting of governance issues. The absence of a journalist union aggravates the situation because employers can hire and fire at will.

Various concerns have been raised about why journalists are quick to cover press conferences organised by certain ministers. I recall a press conference I attended on Christmas Eve 2003 by a government backbencher. The backbencher, who was also the parliamentary leader of a political party, was merely welcoming a new MP into his camp, but the number of reporters present was comparable with the Prime Minister's monthly press conferences. After the press conference, I noticed the MP beckoning my colleagues to follow him to his office. I tagged along and, there in his office, he handed out bundles of K50 notes.

\section{b. Media organisations}

Media organisations are pressed to make money. Advertising rates have increased significantly and so have other costs, such as talkback, which were once free. Today for one hour's talk on HIV/AIDS, corruption or the environment, there is a fixed charge of between $\mathrm{K} 3,000-5,000$. It seems that making money is more important than promoting governance for a better PNG. Since their corporatisation, media organisations such as the NBC have been urged to make money, despite its mandate to inform Papua New Guineans. The ratio of news to advertisements is 60:40. Peter Aitsi, President of the PNG Media Council, admitted at the 2005 Media Freedom Day at the University of PNG that the media had obligations to its shareholders. Addressing students during the celebration, he said the media was a service provider and shareholders expected some form of return for their investment. 


\section{c. The public's perception}

The consumer focuses on what concerns him most. He will attend to his own parochial needs rather than worry about issues such as governance. If the issues propagated are linked to him/her, time is set aside to deal with this. Other than that, people get carried away doing their own thing. Take the sales of newspapers during the State of Origin rugby series, when rural provinces have significant sales, compared with ordinary days.

\section{d. Access to media}

Rural areas have limited access to media services. Mike Jeliffe, Missionary Aviation Fellowship's (MAF) director of operations, says scores of people greet his planes during their trips to rural areas. To them, access to the world in information terms is through the MAF. Few communities have electricity for television or radio and the literacy rates are very low.

\section{e. Government information}

The PNG Government has attempted to reach the population through some of its initiatives. They include the City Sivarai, which is produced by the Department of Information and Communication, and government talkback radio. The former is printed at the Government Printing Office and distributed through the main government offices and inserted into the Post-Courier, The National and Wantok. It is written in English, Tok Pisin and Motu.

Government talkback radio is coordinated by the Information and Communication Office in conjunction with the NBC. According to the Acting Secretary for Information and Communication, a lot of departments have expressed interest in using the Sivarai. However, with limited space, it cannot accommodate everyone's interests, and, in any case, it concentrates on the Government's positive achievements at the expense of educating and informing its readers. Ward (2000) describes this practice eloquently: governments everywhere have learned the art of 'packaging the news', of steering journalists towards covering the news stories they want and in the form they want, and the PNG Government is no different.

\section{f. Use of paid advertisements for governance issues}

As well as the government media, the use of paid advertisements is a regular option. The British High Commission has a weekly one-hour program on FM100 which features people such as the Public Prosecutor, Chronox Manek, speaking on a multitude of governance issues. Inserts into newspapers are paid for and even the use of coloured advertisements is a regular feature, in this case by PNG's Transparency International. 


\section{g. Locally driven agendas}

There are no local, indigenous movements opposing corruption that can be supported by the PNG media, which must therefore work out exactly how it can dissect global issues and present them to the public. The media could easily promote how to be a responsible Papua New Guinean. It could also push issues about being a successful Papua New Guinean. So far, environmental groups such as Eco Forestry Forum have pushed for stringent control of logging practices, which are a global and local issue. The media does not endeavour to encourage home-grown issues; it plays a stereotyped role, opting to present news and information and not worrying about its effects, even if it exacerbates a situation.

\section{h. Coordinated campaigns}

The PNG media, if it was really serious, should address issues in a coordinated fashion. That means structuring carefully how each message is to be presented. At the moment, it takes on any issue as long as there is funding. There is no regard to whether readers are aware of the relevance particular information has for them. Former chief of staff of the PNG Defence Force, Colonel Leo Nuia, writing in the Post-Courier on July 29, 2005, accused the Gun Control Committee of wasting its time: 'I have decided to write to the Guns Control Committee because I do not believe all the publicity so far has been balanced. It seems that the campaign against guns has been stage-managed and views to the contrary [have] been ignored and played down.'

\section{i. Taking for granted the reader's ability to understand}

I believe one of the professional cardinal sins committed by journalists in PNG is to assume that everyone understands and interprets information as they do. This notion has been the subject of a lot of debate with the media claiming that it is up to readers to understand, and that they try to simplify the information wherever possible.

\section{j. The media's adaptation of foreign issues}

Finally I believe that the PNG media prides itself on being on par with the rest of the world. It attempts to relay, print and use syndicated pieces of news all in the context of giving the consumer the cutting edge in whatever service it provides. Global issues such as children's rights, poverty, gender equity and even governance were quickly embraced by the media organizations; however, there was no attempt to relate this to the common people. Take the issue of poverty: the World Bank had stated that PNG was on a poverty line, yet Papua New Guineans vehemently refused to accept that.

Sarah Garap (2003), a prominent Highlands woman, reported that no Papua New Guinean had ever died of starvation and or because of a lack of access to services, because of the presence of wantoks. According to Garap, the global definition 
of poverty had no bearing on the local folk and its constant use in the media was insulting and derogatory to Papua New Guineans. Shelley Launa (2005), a community development worker, is sceptical about women's rights in the country. She believes that in a male-dominated society, men will embrace and accept the efforts of women only if they coexist with the menfolk.

\section{Conclusion}

The media has no obligation to publicise any specific issue and addresses each issue when it arises. Media companies want to make money, often at the expense of good governance, despite giving rebates like free coverage up to a certain point. In other words, the media's prime mandate is to make money and survive.

Reporters are well trained yet underpaid, and there is often a lack in the depth of their experience. Former Prime Minister Sir Julius Chan (1995) concludes succinctly: 'It would be better to have experienced senior journalists assigned to write [about] important subjects, rather than young journalists who often have no sense of history and appear to have been assigned to a task simply because they are on duty and there is an assignment.' And, even if issues are presented, most Papua New Guineans don't grasp the essence of the issues that are being reported.

Morris Dogimai, chairperson of the Wakawa Theatre, and his team visited 436 villages between Oro and Central Provinces and were astounded to find that people still weren't attuned to the mass awareness programs promulgated by the National AIDS Council. This stark reality shows that outside observers are mistaken if they think that the PNG media has adequately addressed key issues facing the country. Because of a lack of a coherent, precise and simple message, the bulk of the populace remain marginalised.

While the media has shown that it can cover global and governance issues, it neglects its potential to be a responsible partner in PNG's development. As Chan says, 'Perhaps if it was seen less as a product, a commodity, a source of ratings and income, and more as the lifeblood of democracy and freedom, more as the people's right to know the truth, then we would have a better source of news in the world today.'

\section{Recommendations}

1. Review the role of PNG media organisations in relation to their performance and ascertain if the media has too much freedom. Establish a committee to re-examine whether it has been consistent with its perceived role and whether the Independent Media Standards Commission has implemented its aims.

2. Strengthen the Office of Information in PNG with improved facilities and funding and use provincial governments to open information offices. Officers 
should be employed by this department but attached to the respective provincial governments. The office could also pour more resources into the NBC and consider having its own television station.

3. Use the Army for patrols to remote areas, with members of the infantry to be engaged in the dissemination of information as part of their civic responsibility. This can be done twice a year and good governance can be promoted and marketed.

4. The school curriculum needs to promote and reinforce patriotic values. Traditional governance principles should be adapted, reinforced and made an integral part of the curriculum in each of the 19 provinces. This will enable students to relate to their own values and then embrace national governance issues.

5. Establish and strengthen the Journalists' Union so that it can fight for the rights of journalists, ensuring that journalists have better conditions, are content with their jobs and perform well. Currently they work long hours, are underpaid and are prone to bribery, intimidation and lack of interest.

6. Establish an Independent Centre for Journalism that can support good governance and fight corruption. It can be linked with other international bodies such as the Australian Centre for Independent Journalism and the Philippines Centre for Independent Journalism.

7. Build the capacity of PNG journalists. They need to spend time with overseas-based governance organisations and undertake training, particularly with regard to issues of good governance.

\section{References}

\section{Media}

'Cheezed Off, UPNG', Post-Courier, 'Viewpoint', 25 July, 2005.

Dogimai, Morris, 'HIV awareness not reaching majority', Post-Courier, August 10, 2005.

Felt, Mark, 'Deep Throat sparks media debate', Post-Courier, June 3, 2005.

Garap, Sarah, at the Enga Maseamana meeting, Wabag, November 2003.

Honimae, Johnson, ABC, Pacific Beat, Thursday July 7, 2005.

Nuia, Leo, 'Law and Order - Illegal Guns', Post-Courier, July 29, 2005.

Pamba, Kevin, 'The Ripple effects of Western Bias', The National, July 27, 2005.

Solomon, Anna, at the Reporting Law and Order conference, Vunapope Conference Centre, Rabaul, May 8, 2005.

'The Insider, Part II, Waigani', Post-Courier, July 27, 2005. 


\section{Scholarly}

Aitsi, Peter John. 2005. Address at the 2005 Media Freedom Day, University of Papua New Guinea, May 1.

Brookfield, H. C. 1972. Colonialism, Development and Independence: The Case of Melanesian Islands in the South Pacific. Cambridge: Cambridge University Press.

Chan, Julius. 1995. 'Serving truth with development news.' Pacific Journalism Review, 2, 1 .

Kanekane, Joe. 2003. 'Challenges in Reporting Corruption in Newspapers.' In David Kavanamur, Charles Yala and Quinton Clements (eds), Building a Nation in Papua New Guinea: Views of the post-independence generation, Canberra: Pandanus Books.

Maino, Charles. 1995. 'People, News and Government.' Pacific Journalism Review, 2,1 .

Molloy, Ivan (ed.) 2004. Eye of the Cyclone: Issues in Pacific security. Maroochydore, Qld: Sunshine Coast University College.

Pearson, Mark. 2001. 'Journalists are different from their audiences.' Pacific Area Newspaper Publishers' Association Bulletin, 209. p. 26.

United Nations Research Institute for Social Development. 1995. States of Disarray: The social effects of globalization. An UNRISD report for the World Summit for Social Development. Geneva, Switzerland.

Ward, Ian. 2000. 'A genuinely free press?' Pacific Journalism Review, 6, 1. pp. 13-14.

Stiglitz, Joseph. 2002. Globalization and its Discontents. New York and London: W. W. Norton.

\section{Conversations}

Daniel Kapi, telephone interview, October 2002

Daniel Korimbao, telephone interview, July 2005

Shelley Launa, Community Justice Liaison Unit, June 2005 